\title{
LA SUBVENCIÓN ADMINISTRATIVA: CONCEPTO Y RÉGIMEN JURÍDICO ${ }^{* * *}$
}

AdminisTRATIVE SUBSIDIES: CONCEPT AND LEGAL REgIME

LA SUBVENTION ADMINISTRATIVE: CONCEPT ET SYSTÈME JURIDIQUE

William García Machmar ${ }^{* * *}$

RESUMEN

El artículo analiza el concepto y el régimen jurídico de las subvenciones o ayudas públicas, desde el punto de vista del Derecho Administrativo junto a un profundo análisis de la legislación chilena. El autor defiende la idea que la subvención crea una relación jurídica entre la Administración y el beneficiario y describe los derechos, deberes y potestades de cada uno.

PALABRAS CLAVE: Subvención administrativa - Interés público - Caducidad subvención

ABSTRACT

The article analyses the concept and legal regime of subsidies or public aides, from an Administrative Law point of view, along with a profound analysis of the Chilean legislation. The author argues in favour of the idea that a subsidy creates a relationship between the Administration and the beneficiary and describes the rights, duties and powers of each party.

KEY WORDS: Administrative subsidies - Public interest - Expiration of subsisdies

RÉSUMÉ

Cet article analyse la notion et le régime juridique des subventions ou aides publics, $d u$ point de vue du droit administratif par une analyse approfondie de la loi chilienne. L'auteur défend l'idée que la subvention crée une relation juridique entre l'administration et le bénéficiaire et décrit les droits, devoirs et pouvoirs de chacun.

Mots CLÉS: Subvention administrative - Intérêt public - Subvention d'expiration

* El artículo fue aprobado para su publicación el 14 de septiembre de 2012.

** El presente trabajo constituye una versión muy resumida y actualizada de mi tesis de magíster titulada "Ayudas públicas. La subvención en el Derecho Administrativo", que fue calificada con la nota máxima en abril de 2011 por una comisión compuesta por los profesores Dra. Maricruz Gómez de la Torre, Dr. Luis Cordero Vega y Dr. Eduardo Cordero Quinzacara, cuyas observaciones han sido recogidas en esta versión. Estuvo presente también mi profesor guía don Carlos Carmona Santander, a quien debo una enorme gratitud como educador y maestro.

${ }^{* * *}$ Abogado. Licenciado en Ciencias Jurídicas y Sociales de la Universidad de Chile. Magíster en Derecho, mención Derecho Público, Universidad de Chile. 


\section{INTRODUCCIÓN}

El objeto del artículo es presentar los resultados de mi investigación relativa al concepto y régimen jurídico de las subvenciones, como una técnica especial de intervención administrativa en la economía y en la vida social. Para esta investigación se han analizado cientos de normas legales, reglamentarias e, incluso, circulares administrativas. De esa observación se han sacado conclusiones dogmáticas a la luz de nuestra tradición jurídica que es tributaria del derecho europeo continental.

La exposición se divide en tres partes. En la primera (1) se ubica a la subvención dentro del contexto de la actividad administrativa. En la segunda (2) se entrega un concepto jurídico de subvención. En la tercera parte (3) se explica el régimen jurídico que origina la relación subvencional entre el órgano administrativo otorgante y el beneficiario.

\section{LA SUBVENCIÓN DENTRO DE LA ACTIVIDAD ADMINISTRATIVA}

\subsection{El fomento administrativo y sus medios}

El otorgamiento de subvenciones ha planteado en la dogmática administrativa la necesidad de explicar su ubicación sistemática dentro del contexto de la actividad material de la Administración.

En la tradición hispanoamericana se encuentra muy extendida la noción de fomento administrativo, esto es, la acción de la Administración encaminada a proteger o promover aquellas actividades, establecimientos o riquezas debidos a los particulares y que satisfacen necesidades públicas o se estiman de utilidad general, sin usar de la coacción ni crear servicios públicos ${ }^{1}$. En consecuencia, aparece como una alternativa a la actividad administrativa de servicio público y de policía.

Se ha considerado siempre a la subvención como un típico "medio económico de fomento”, según la clasificación clásica de medios honoríficos, jurídicos y económicos.

"Entre los medios de fomento honorificos comprendemos las distinciones y recompensas que se otorgan como público reconocimiento y proclamación de un acto o de una conducta ejemplar"2.

"Los medios de fomento económicos son todos aquellos que de un modo directo determinan la percepción de una cantidad o la dispensa de un pago obligatorio"3.

"Los medios de fomento jurídicos se caracterizan por el otorgamiento de una condición privilegiada que, de modo indirecto, representa ventajas económicas o de seguridad"4.

\footnotetext{
${ }^{1}$ Jordana DE POZAS, Luis (1949). "Ensayo de una teoría del fomento en el derecho administrativo". Revista de Estudios Políticos, No 48, p. 46.

2 Jordana de POZAS (1949), p. 52.

${ }^{3}$ JoRdANA DE POZAS (1949), p. 53.

${ }^{4}$ Jordana de POZas (1949), p. 53.
} 
Nuestro Tribunal Constitucional ha enunciado, junto con un concepto constitucional de fomento, una cierta tipología de sus medios. En efecto, en sentencia Rol No 1295, de 2010, distinguió entre beneficios y gravámenes En ambos casos, el legislador queda facultado para establecer una relación jurídica, con derechos y obligaciones recíprocas, entre el órgano encargado de materializarlas y el privado que las recibe o soporta (C. 89\%). Entre los beneficios, distinguió, de manera similar al derecho español, entre ayudas honoríficas, jurídicas y económicas. Luego, las ayudas económicas pueden ser directas o indirectas, según si transfieren recursos a un particular o si el Estado deja de cobrar una suma (C. 90º).

La idea de fomento, que ha sido sumamente útil para explicar las subvenciones en nuestra tradición, sólo ha tenido una recepción muy marginal fuera de los países hispanoamericanos, particularmente en Francia ${ }^{5}$ y Alemania ${ }^{6}$, aunque, desde luego, la técnica subvencional sí existe en dichos países.

\subsection{La teoría de las "ayudas públicas" como alternativa al fomento}

En contraste con la teoría tradicional hispanoamericana, autores como MARTíNEZ López MuÑIZ y De la Riva han propuesto reemplazar el concepto de fomento administrativo por el de "ayudas públicas", las que se han definido como toda dispensación mediata o inmediata de bienes a determinados administrados de forma directa o indirecta, con carácter no devolutivo y en razón de ciertas actividades que les son propias, a cuya realización dichos bienes quedan afectados ${ }^{7}$.

Como sostiene De la Riva, "lo que destaca en el área de la actividad administrativa estudiada y obra como presupuesto para la identificación del elemento configurador que estamos buscando es la coincidencia, al menos parcial, que se advierte en el fomento entre los intereses públicos y privados involucrados, ya que ambos se orientan en el mismo sentido" ". Agrega que "estamos, indudablemente, ante un talante distinto de aquel en que la autoridad impone coactivamente su voluntad a los particulares, o de aquel otro en que asume ella misma la satisfacción de las necesidades públicas"'.

En segundo lugar, se destaca por la doctrina que en las ayudas públicas, lo que forma parte inherente del concepto, es que la entrega de la ayuda está afectada al cumplimiento del interés público.

\footnotetext{
${ }^{5}$ Rivero, Jean (1984). Derecho Administrativo. Caracas, Universidad Central, Edición original de 1980, p. 454. En el mismo sentido, Rivero Jean y Waline, Jean (2000). Droit Administratif. París: Dalloz, $18^{a}$ Edición, p. 424.

${ }^{6}$ Stober, Rolf (1992). Derecho Administrativo Económico. Madrid: Marcial Pons, Edición original 1989, pp. 175 y ss.; y Schmidt-Assmann, Eberhard (2003). La Teoría General del Derecho Administrativo como sistema. Madrid: Marcial Pons, pp. 183 y ss.

${ }^{7}$ De la Riva, Ignacio (2004). Ayudas Públicas. Buenos Aires: Editorial Hammurabi, pp. 122-123.

${ }^{8}$ De la Riva (2004), p. 116.

${ }^{9}$ De la Riva (2004), p. 116.
} 
Precisamente, ha sido MARTínez LóPEZ-MuNiz quien sostuvo que:

"Lo que se da -o se dispensa- en concepto de ayuda... no se otorga para ser simplemente consumido o usado, porque con ese uso o consumo se satisface en sí misma una determinada necesidad de otro, sino que siempre se concede en atención a una determinada actividad o conducta que, con la ayuda, va a ser posible o más fácil y mejor realizada" 10 .

"Son, por tanto, las ayudas ventajas afectadas, beneficios vinculados a cierta actividad del beneficiario" 11 .

\subsection{Recepción de estas nociones en la doctrina y en las instituciones chilenas \\ a. Las técnicas de fomento en nuestra historia}

El fomento de las actividades productivas, entendido como una finalidad del Estado, ha estado presente durante toda nuestra historia, bajo distintos sistemas económicos y políticos. Incluso durante las épocas más "liberales" (1830-1930 y desde 1973) el fomento público cumple un papel fundamental en el impulso económico.

Sin embargo, es necesario anotar que hay una diferencia de "sentido" con la intervención estatal que se vive en aquellos momentos de mayor intervención estatal (siglo XVIII ${ }^{12}$ y entre 1930 y $1973^{13}$ ).

En los períodos “liberales", el Estado asume como su responsabilidad el crear las condiciones que permitan un desarrollo comercial e industrial, el cual pertenecía "naturalmente" a los empresarios privados ${ }^{14}{ }^{15}$. Se reconoce una comunidad de intereses entre Estado y empresariado, nacional y extranjero.

\footnotetext{
${ }^{10}$ López Muñiz, José Luis (1989). "La actividad administrativa dispensadora de ayudas y recompensas: una alternativa conceptual al fomento en la teoría de los modos de acción de la Administración Pública". En: Libro homenaje al profesor José Luis Villar Palasí, Gómez-Ferrer Morant, Rafael (Coord.), Madrid: Civitas, p. 757.

${ }^{11}$ LÓPEZ MuÑiz (1989), p. 760.

${ }^{12}$ Un análisis de la institucionalidad de la Ilustración española en su perspectiva jurídico-política en EyZAguirre, Jaime (1959). Historia del Derecho. Santiago: Editorial Universitaria, pp. 241 y ss. Véase también FigueroA, María Angélica (1980). "El Tribunal del Consulado de Chile y la política de fomento económico de los Borbones". En: V Congreso del Instituto Internacional de Historia del Derecho Indiano: realizado en Quito-Guayaquil, T. II, pp. 187-206; JocelYn-Holt LeTELIER, Alfredo (2009). La independencia de Chile. Tradición, modernización y mito. Santiago: Random House Mondadori, p. 89.

${ }^{13}$ Cepal (1954). Antecedentes sobre el desarrollo de la economía chilena. 1925-1952. Santiago: Editorial del Pacífico, p. 144.

${ }^{14}$ Villalobos y Sagrado defienden la idea de una permanencia de la doctrina y prácticas proteccionistas en todo el siglo XIX (Villalobos R., Sergio y Sagredo B., Rafael (1987). El proteccionismo económico en Chile. Siglo XIX. Santiago: Instituto Blas Cañas); Sunkel, Osvaldo y Cariola, Carmen (1982). La historia económica de Chile 1830-1930. Dos ensayos y una bibliografía. Madrid: Ediciones Cultura Hispánica del Instituto de Cooperación Iberoamericana.

${ }^{15}$ Büchi Buc, Hernán (1993). La transformación económica de Chile. Del estatismo a la libertad económica. Bogotá: Editorial Norma. Un análisis crítico de la política económica 1990-2010, con énfasis en la continuidad con el período 1975-1989, en FAzIO, Hugo y PARADA, Magali (2010). Veinte años de politica económica de la Concertación. Santiago: Lom Ediciones.
} 
En cambio, en los períodos intervencionistas el Estado se atribuye a sí la función de prestar directamente los servicios y proveer de los bienes necesarios para el bienestar de la sociedad; aunque para ello recurra continuamente a la colaboración privada, mediante concesiones u otras técnicas como la subvención.

Una manifestación de la continuidad del fomento es la existencia hasta hoy en día de instituciones creadas en el período 1930-1973 (o incluso antes), que ejecutan políticas de ayudas públicas: la $\mathrm{CORFO}^{16}$ y la Caja de Crédito Prendario.

De la observación histórica podemos concluir que el fomento prospera en los períodos de mayor estabilidad política. Ello demuestra que es una manifestación de soluciones de compromiso, donde existen los medios institucionales para alcanzar arreglos políticos duraderos.

\section{b. Recepción del fomento o "ayudas públicas" en la doctrina nacional}

La doctrina se ha visto enfrentada a tener que otorgar un fundamento racional a la presencia histórica del fomento administrativo. Esta explicación ha sido distinta según las diferentes "escuelas" del derecho administrativo. Se sostiene que son verdaderas escuelas de pensamiento, primero, por la unidad doctrinaria que existe entre los autores, que sigue paralela a la doctrina comparada y, segundo, por la consistencia histórica entre ellas, es decir, todas ellas explican fuentes positivas similares.

Entre los primeros autores, de la escuela de la policía administrativa, este tipo de actividad se comprende dentro de la policía del bienestar ${ }^{17}$.

Posteriormente, en el siglo XX, la escuela del servicio público entendía a las subvenciones como la técnica creadora de "establecimientos de utilidad pública", siguiendo la explicación de Jezè ${ }^{18}$.

Hoy en día, las subvenciones se ven como una manifestación de la Administración "al servicio de la persona", aunque con justificaciones ideológicas bien distintas, según sea el autor.

Por una parte, Eduardo Soto interpreta la cláusula de "servicialidad del Estado" como estableciendo un "Estado subsidiario". A su juicio, "el concepto del inciso $4^{\circ}$ del artículo $1^{\circ}$ contiene un mandato, simultáneo y elocuente, que es al mismo tiempo un rechazo y una invitación. Un rechazo a concebir el Estado como 'un agente de actividades encaminadas a la obtención de objetivos que él mismo señala

\footnotetext{
${ }^{16}$ En general, sobre la CORFO véase OrTega MarTínez, Luis et al. (1989). Corporación de Fomento de la Producción. 50 años de realizaciones: 1939-1989. Departamento de Historia, Universidad de Santiago de Chile, Santiago.

${ }^{17}$ Letelier Madariaga, Valentín (1904). Apuntaciones de Derecho Administrativo. Santiago, p. 107; AmUnátegui, Domingo (1907). Tratado Jeneral de Derecho Administrativo. Santiago, pp. 215-220.

${ }^{18}$ Iribarren, Juan Antonio (1935). Lecciones de Derecho Administrativo. Santiago: Nascimento, pp. 23, 111-112; Merino, Ernesto (1936). Derecho Administrativo. Santiago: Imprenta Universitaria, p. 62; VAras Contreras, Guillermo (1948). Derecho Administrativo. Santiago: Editorial Nascimento, 2a Edición, pp. 14-15, 177 y ss.; Daniel Argandoña, Manuel (1960). Derecho Administrativo. Santiago: Edugal, T. I, pp. 307-308; Silva Cimma, Enrique (1969). Derecho Administrativo Chileno y Comparado. Santiago: Editorial Jurídica de Chile, 2a Edición, p. 351.
} 
para su propio provecho y engrandecimiento', en una perspectiva que 'pretenda buscar beneficios colectivos en sacrificio del hombre mismo'; y una invitación que se traduce en el comprometerse en una concepción decidida y profunda de lo que entiende por persona humana y sus características"19.

Por otra parte, en contraste, otros autores interpretan la cláusula de "servicialdiad” del Estado como consagrando el Estado Social en nuestra Constitución.

El autor que más atención ha dedicado al tema es Rolando Pantoja, el que afirma que "la Constitución Política de la República proyecta hacia la finalidad propiamente administrativa del Chile actual, uno de los aspectos en que descansa la matriz teleológica del administrativismo democrático: el desarrollo sustentable, que aúna impulso y equilibrio, desarrollo y medio ambiente" 20 . A lo que agrega que "En verdad, actualmente no se trata de reconocer o hacer del Estado la fuente de todo progreso y cambio socioeconómicos, sino de establecer la responsabilidad compartida entre la sociedad civil y el Estado en la obtención de un resultado de bien común... En este sentido, la Constitución formula un abierto y explícito llamado a contribuir de una manera efectiva a alcanzar el bien común... En síntesis, la función administrativa en el Estado de Chile del siglo XXI es una actividad prestacional, conformadora socioeconómica para el desarrollo sustentable del país y creadora de las 'condiciones sociales que permitan a todos y a cada uno de los integrantes de la comunidad nacional su mayor realización espiritual y material posible, con pleno respeto a los derechos y garantías que esta Constitución establece', en un contexto filosófico humanista y solidario, jurídicamente determinado por un sentido sustancial y teleológico en la aplicación de las normas que rigen su ser y actuar" ${ }^{21}$.

En cualquier caso, en las obras generales, ha ganado aceptación la clasificación tradicional española, ya analizada, de la actividad administrativa: policía, fomento y servicio público. $\mathrm{Al}$ respecto pueden verse las obras de PANTOJA BAUZÁ ${ }^{22}$ y de BERMÚDEZ Sото $^{23}$. Asimismo, en los programas de estudio es la clasificación más aceptada ${ }^{24}$.

\footnotetext{
${ }^{19}$ Sото KLoss, Eduardo (2009). Derecho Administrativo. Temas Fundamentales: Santiago: LegalPublishing, p. 110.

${ }^{20}$ Pantoja BauzÁ, Rolando (2007). "El Derecho y la Administración del Estado en Chile”. En: Derecho Administrativo Chileno, Pantoja BauZÁ, Rolando (Coord.), México D.F.: Editorial Porrúa, p. 68. En idéntico sentido en PANTOJA BAUZÁ, Rolando (2008). "La tipología asumida por la Administración Pública como función estatal en su proceso adaptativo a la evolución experimentada por el Estado moderno constitucional: desde la summa potestas a la concreción humanista de la solidaridad”. En: Derecho Administrativo. 120 años de Cátedra, Pantoja BauzÁ, Rolando (Coord.), Santiago: Editorial Jurídica de Chile, pp. 196-197.

${ }^{21}$ Pantoja Bauzá (2007), pp. 90-91. En idéntico sentido en Pantoja Bauzá (2008), p. 220.

22 Pantoja Bauza (2007), p. 407. Capítulo a cargo de Gladys Camacho. En idéntico sentido, Pantoja BauzÁ, Rolando (2010). Tratado de Derecho Administrativo. Santiago: Abeledo-Perrot LegalPublishing, T. IV.

${ }^{23}$ Bermúdez Soto, Jorge (2010). Derecho Administrativo General. Santiago: Abeledo-Perrot LegalPublishing, passim.

${ }^{24}$ Véase, por todos, el Programa del Curso de Derecho Administrativo de la Facultad de Derecho, Universidad de Chile. Disponible en: <www.derecho.uchile.cl> [consulta: noviembre 2010].
} 


\section{CONCEPTO Y NATURALEZA JURÍdica}

\subsection{Concepto amplio y concepto restringido}

En el derecho administrativo se ha discutido el empleo de un concepto amplio o uno restringido de subvención ${ }^{25}$. El concepto amplio entiende por subvención todo beneficio económico percibido de la Administración con objeto de fomentar o impulsar determinadas actuaciones que pueden considerarse de interés general. Con este concepto se abarcan prácticamente todas las medidas de fomento económico ${ }^{26}$.

Sin embargo, la doctrina mayoritaria acoge un concepto restringido, esto es, "atribución patrimonial, principalmente entrega de dinero, que se recibe de la Administración a fondo perdido y que moralmente debe ser aplicado a una determinada finalidad" 27 .

En este trabajo se empleará la concepción estricta de subvención, atendiendo más bien a su estructura jurídica y no, exclusivamente, a su perspectiva finalista -de promoción o estímulo económico- en un sentido similar a FERNÁNDEZ FARRERES ${ }^{28}$.

A nuestro juicio, el concepto estricto es el que más se aviene con el derecho positivo nacional, toda vez que la finalidad perseguida es un elemento accesorio o secundario a la luz de la estructura jurídica de la subvención, particularmente, para explicar el conjunto de potestades que la ley otorga a la Administración para asegurar la vinculación de los fondos al servicio del interés público por el particular beneficiario.

En segundo lugar, porque los medios específicos a través de los cuales se fomenta la economía son variados y el derecho positivo los dota de regímenes diversos ${ }^{29}$. Conviene, aunque sólo sea por lograr la claridad en el estudio de los distintos fenómenos, estudiarlos por separado.

En tercer lugar, el concepto restringido de subvención resalta el carácter instrumental de la subvención: que el particular se encuentra en la necesidad jurídica de realizar ciertas prestaciones y que la Administración posee un poder de intervención que tiene por causa y origen a la subvención ${ }^{30}$.

\footnotetext{
${ }^{25}$ El debate en la doctrina española, influida por la ubicación de la actividad subvencional dentro de las técnicas de fomento económico, puede verse en Fernández Farreres, Germán (1987). "De nuevo sobre la subvención y su régimen jurídico en el derecho español”. Revista de Administración Pública, No 113.

${ }^{26}$ Martín-Retortillo Baquer, Sebastián (1988). Derecho Administrativo Económico. Madrid: La Ley, T. I, p. 451; y MaLjaR, Daniel (1998). Intervención del Estado en la prestación de servicios públicos. Buenos Aires: Editorial Hammurabi, p. 294.

${ }^{27}$ Martín-Retortillo Baquer (1988), pp. 450-451.

${ }^{28}$ Fernández FarReres, Germán (1983). La subvención: concepto y régimen jurídico. Madrid: IEF, p. 71.

${ }^{29}$ FernándeZ Farreres (1987), p. 44.

30 "En tal concepto concurren, de forma fehaciente por demás, las dos notas que con carácter general se establecieron como determinantes de la actividad administrativa de fomento. Por una parte, su carácter instrumental con el fin de que el sector privado lleve a cabo determinadas actuaciones. También, técnica
} 


\subsection{Elementos de la definición de subvención}

Hemos definido a la subvención, apegándonos a la obra de Germán FernánDEZ FARRERES e Ignacio DE LA RIVA, como aquella "transferencia patrimonial no devolutiva, realizada por la Administración en favor de un particular, vinculada a la realización por éste de una conducta calificada de interés público"ß1. De esta definición se extraen elementos objetivos, subjetivos y teleológicos.

\section{a. Elemento objetivo}

Ante todo, desde el punto de vista del objeto ${ }^{32}$, la subvención consiste en una transferencia patrimonial ${ }^{33}$.

Aunque normalmente esta transferencia de carácter económico recaerá sobre una suma de dinero, esto es, sobre fondos presupuestarios, FERNÁNDEZ FarRerEs concibe que la subvención puede consistir en dinero u otra clase de bienes ${ }^{34}$. En cambio, otros autores consideran que siempre ha de consistir en dinero ${ }^{35}$.

Es necesario agregar que la atribución subvencional es siempre no devolutiva, es decir, a fondo perdido ${ }^{36}$. Sobre este punto hay prácticamente unanimidad en la doctrina ${ }^{37}$.

Lo anterior, no excluye la conversión -prevista por la norma jurídica- de una subvención en una relación distinta (normalmente un préstamo) ${ }^{38}$, por hechos sobrevinientes.

Ello permite distinguir a la subvención de la exención tributaria -en que no hay transferencia-, de la devolución de impuestos -en que se restituye lo que ya

de ordenación por la Administración pública de esas mismas actuaciones. Dos notas que las subvenciones evidencian de forma muy manifiesta”. MarTín-Retortillo Baquer (1988), p. 477.

${ }^{31}$ Fernández Farreres, Germán (2005). “Subvenciones”. En: Diccionario de Derecho Administrativo, Muñoz Machado, Santiago (Dir.), Madrid: Editorial Iustel, T. II, p. 2474.

${ }^{32}$ De la Riva (2004), p. 164, trata conjuntamente con el objeto el carácter finalista de la subvención. En esta parte seguiremos el sistema de Fernández Farreres, que los separa.

${ }^{33}$ Fernández Farreres (1983), p. 78.

${ }^{34}$ Fernández Farreres (1983), p. 97; Martín-Retortillo Baquer (1988), p. 481; Gimeno Feliú, José María (2005). "La técnica de fomento del desarrollo económico: la subvención”. En: Derecho administrativo. Parte especial, Bermejo Vera, José (Dir.), Madrid: Thomson-Civitas, 6a Edición, p. 946.

35 Santamaría Pastor, Juan Alfonso (2006). Sobre la génesis del Derecho Administrativo español en el siglo XIX (1812-1845). Madrid: Iustel, T. II, p. 356.

36 Fernández Farreres (1983), p. 107; Martín-Retortillo Baquer (1988), p. 481, y Gimeno Feliú (2005), p. 946.

${ }^{37}$ Cassagne conserva la denominación de subvención para algunos casos en que hay lugar a restitución: "En principio, la subvención no genera contraprestación o compensación, salvo que hubiera al respecto alguna estipulación expresa establecida en un acto o contrato administrativo" (CASSAGNE, Juan Carlos (2006). Derecho Administrativo. Buenos Aires: LexisNexis, $7^{\text {a }}$ Edición, T. II, p. 468).

${ }^{38}$ FERNÁNDEZ FARRERES (1983), p. 109. 
se pagó- de la garantía estatal -en que se paga una obligación ajena, con cargo a su restitución-y de los créditos -que crean la obligación de restituir-.

\section{b. Elemento subjetivo}

Debido que la subvención establece una relación jurídica entre dos sujetos tendremos siempre, en un extremo, un otorgante y, en el otro, un beneficiario.

De un lado, el otorgante siempre será un órgano de la Administración del Estado, esto es, un ente dotado de patrimonio público -aunque este patrimonio se haya formado parcialmente con donaciones privadas-.

El caso más paradigmático es del Fondo Mixto de Apoyo Social que es formado con el 33\% de las donaciones de personas jurídicas, regidas por la Ley No 19.885 . El resto de este patrimonio se forma por los aportes de la Ley de Presupuestos, de ahí que se le denomine "mixto".

Además, pueden encontrarse los llamados fondos concursables, que son patrimonios públicos afectados al financiamiento de actividades privadas de interés público, y que se forman también por aportes privados. Ciertamente, se trata de patrimonios públicos, pues una vez adquiridas las liberalidades por el respectivo OAE, pierden su naturaleza jurídico privada.

En materia de fomento a la recuperación de barrios, las ayudas son financiadas directamente por el presupuesto de los respectivos SERVIU. Además, podrán concurrir con aportes adicionales el Gobierno Regional, los Municipios u otros servicios públicos, e incluso personas naturales, corporaciones o fundaciones de ayuda a la comunidad (artículo 4o D.S. No 14 de 2007, Vivienda).

De otro lado, el beneficiario será, en principio un privado, una persona natural o jurídica de derecho privado. En esta materia, como en otras, nuestro derecho público adopta un principio de titularidad amplísimo.

En el caso del fomento a las artes, se reconoce también una amplia titularidad, donde pueden presentarse personas naturales o jurídicas, nacionales o extranjeras ${ }^{39}$.

Con todo, en ciertos casos, la subvención se destina solamente a sujetos que se encuentran en una situación jurídica calificada por un título administrativo previo, o sea, quien ha sido autorizado, certificado, registrado, etc. En el derecho chileno, la Ley No 19.862, establece que a las personas jurídicas que reciban subvenciones sólo pueden percibirlas si se encuentran registradas.

Aun cuando la ley no ha establecido inhabilidades especiales, la Administración debe de todos modos cuidar el respeto a la probidad, como principio general de actuación de la Administración. Acá, es aplicable lo que dispone el artículo

${ }^{39}$ Véanse, D.S. No 65, Educación, sobre Fondo Nacional de Desarrollo Cultural y de las Artes, 25 de marzo de 2004; D.S. No 151, Educación, sobre Fomento Audiovisual, 12 de septiembre de 2005; D.S. No 187, Educación, sobre Fomento a la Música, 25 de octubre de 2004. 
53 LOCBGAE, según el cual la preeminencia del interés general se expresa en la imparcialidad de las decisiones del poder público. Asimismo, según el artículo 62 de la misma ley, se tipifica como una infracción al principio de probidad el intervenir en razón de las funciones en asuntos en que se tenga interés personal o en que lo tengan el cónyuge, hijos, adoptados o parientes hasta el tercer grado de consanguinidad y segundo de afinidad inclusive.

En relación con él, también el artículo 12 LBPA que establece el principio de abstención dispone que las autoridades y funcionarios de la Administración deben abstenerse de intervenir cuando exista un interés involucrado.

Es importante destacar que, por el hecho de recibir una subvención, el receptor no altera su naturaleza jurídica privada. Es decir, no se integra en la Administración del Estado.

Cabe destacar que la Contraloría General de la República ha sostenido, en relación a las entidades que reciben subvenciones, que "en estos entes jurídico está presente de un modo predominante el interés público, y aunque no es posible considerarlos como organismos integrantes de la Administración del Estado, se justifica que se les apliquen determinadas normas que les exigen brindar información o ser controlados en términos similares a los órganos públicos, justamente para resguardar dicho interés y cautelar que la actuación del Estado, a través de ellos, respete la preceptiva orgánica correspondiente, y no adolezca de irregularidades” ${ }^{30}$.

Ahora bien, hemos dicho que esta situación normal sufre alteraciones cuando el beneficiario es un concesionario, o sea, un gestor privado de bienes o servicios públicos, en cuyo caso la subvención actuará como una técnica de mantenimiento del equilibrio económico de la concesión y no como una ayuda pública propiamente tal. Se trata de "una técnica de colaboración financiera de la Administración titular del servicio público concedido con el concesionario" ${ }^{41}$.

Luego, es posible que el beneficiario sea una persona jurídica de derecho público. Tratándose de las empresas públicas, las limitaciones están dadas por los requisitos formales que la Constitución prevé para otorgar estos beneficios: sujeción al derecho común o habilitación especial por ley de quórum calificado.

El Tribunal Constitucional se ha pronunciado en dos ocasiones sobre transferencias a empresas públicas. En 1996 sostuvo que no existía infracción al artículo

\footnotetext{
${ }^{40}$ Contraloría General de la República, Dictamen No 75.508, 15 de diciembre de 2010, y Dictamen No 37.493, 7 de julio de 2010, ambos sobre corporaciones municipales de educación y salud. En el mismo sentido Contraloría General de la República, Dictamen No 31.866, 14 de junio de 2010; Dictamen No 21.456, 24 de abril de 2009; Dictamen No 48.890, de 2007 y Dictamen No 32.256, 11 de julio de 2008.

${ }^{41}$ Fernández Farreres (1983), p. 200. Véase también Martín-Retortillo Baquer, Sebastián (1988), p. 485, para quien en este caso la subvención juega roles muy diversos: "garantizar el equilibrio económicofinanciero de la concesión cubrir el déficit de la explotación en función del cálculo anticipadamente previsto de la misma, bien de forma total, bien hasta un límite determinado; también asegurando un determinado beneficio al concesionario, lo que supone que no sólo se establece con éste una determinada vinculación sino también un auténtico consorcio de riesgos, en cuanto estos son asumidos en parte por la Administración”.
} 
19 No 22, al financiar ENACAR, toda vez que el proyecto no constituía una excepción al derecho común, sino una aplicación de éste ${ }^{42}$. Luego, en 2008 el Tribunal afirmó que se infringía el artículo 19 No 22, toda vez que se otorgaba un beneficio económico a una empresa estatal -BancoEstado y la Cuenta Única de Reembolso del Sistema de Transporte de Santiago- sin estar habilitado por una ley específica ${ }^{43}$.

Llama la atención, finalmente, el caso de las municipalidades, las que muchas veces reciben las subvenciones en igualdad de condiciones que el sector privado (por ejemplo, la subvención a la educación escolar, subvención a la jornada escolar completa, programa de mejoramiento comunitario, fomento a las artes y el fomento a la música). La doctrina entiende que, toda vez que son órganos autónomos, la subvención, en el caso de ellas, no debiera actuar como un mecanismo de dirección y control extraordinario que "derogue" su estatuto de autonomía ${ }^{44}$.

Este empleo generalizado de la misma expresión y el mismo régimen jurídico hacen imposible realizar una distinción clara sobre el régimen, pero es necesario señalar las siguientes precisiones.

Por una parte, la subvención se sujetará no sólo a las reglas propias del régimen jurídico que las instituye, sino que, además, se ajustarán a las normas sobre administración financiera del Estado.

Por otra parte, en materia de control, el estatuto que se aplica a los privados (inhabilidades, medidas rescisorias, etc.), no puede ser trasladado sin más al caso de las municipalidades.

\section{c. Elemento teleológico}

En lo que respecta al elemento teleológico -quizá el más rico en consecuencias dogmáticas de todos- la subvención es siempre una transferencia "afectada a un fin”, o sea, cuya eficacia completa dependerá de que se realice una determinada actividad que se considera de interés público.

\footnotetext{
42 "Que, no se divisa en el proyecto impugnado una discriminación arbitraria al tenor de lo señalado precedentemente, pues éste en definitiva, se limita, tal como se ha dicho a la aplicación del mecanismo legal de la capitalización de ENACAR, no constituyendo, en caso alguno, una excepción a la legislación que regula la actividad empresarial del Estado, razones todas que conducen a que el requerimiento interpuesto sea rechazado". Sentencia Tribunal Constitucional, Rol No 249, C. $10^{\circ}$.

43 "Que, entonces, el préstamo que se analiza permite el desembolso de dinero por parte del mismo Estado (es un crédito conferido por una empresa del Estado como el Banco del Estado) para beneficiar a un sector de la vida nacional: el del transporte público de la ciudad de Santiago para que éste no incremente un alza desmedida de las tarifas que se cobran a los usuarios y, al mismo tiempo, para que no se produzca un desmedro en el funcionamiento del sistema. En otras palabras, se está otorgando un beneficio al sector del transporte público de la ciudad de Santiago por medio de un decreto supremo y no por ley”. Sentencia Tribunal Constitucional, Rol No 1153 , C. $65^{\circ}$.
}

${ }^{44}$ Fernández Farreres (1983), pp. 223-224. 
Ahora bien, este carácter afectado ha sido explicado de distintas maneras: como acto condicional ${ }^{45}$, como acto modal ${ }^{46}$, como un acto que origina una carga ${ }^{47} \mathrm{o}$ como acto que origina un deber jurídico ${ }^{48}$.

A mi juicio, la calificación de DE LA RIVA es la que mejor se adapta a la situación de nuestro derecho positivo, en cuanto explica la actitud que adopta la Administración frente al incumplimiento del infractor.

En la práctica, la conducta desviada del beneficiario se enfrenta de una manera gradual. La Administración reaccionará dirigiendo la acción del incumplidor a la conformidad con la norma. La ineficacia de la subvención estará dada por causales tasadas o por la imposibilidad total de llevar al beneficiario a adecuarse a la norma. Por lo tanto, no resultan útiles las nociones de condición o modo empleadas por la doctrina comparada.

Además, en virtud de la Ley No 20.500, sobre asociaciones y participación ciudadana en la gestión pública, contamos ya en nuestro derecho con una definición que entrega criterios hermenéuticos sobre qué debe entenderse como una entidad privada que persigue fines de interés público (aunque, en principio la definición de la ley es sólo para las personas jurídicas). Se entiende por tal una entidad cuya finalidad es la promoción del interés general, en materia de derechos ciudadanos, asistencia social, educación, salud, medio ambiente o cualquier otra de bien común, en especial las que recurran al voluntariado (artículo 15).

El carácter afectado de las ayudas es, como se justificará a lo largo de este trabajo, el título que sirve de fundamento a las potestades de intervención de la Administración otorgante.

El Tribunal Constitucional ha destacado que:

"Alotorgar estos beneficios, el legislador puede perfectamente establecer condiciones o requisitos para su obtención o para su mantención, para lograr la finalidad pública que se busca obtener con la transferencia. Estas transferencias no son un regalo, sino una donación moral o condicionada al cumplimiento de determinados fines para recibirlos $y$ al logro de resultados que se estiman valiosos" (STC Rol No 1295, C. 90).

Es justamente para lograr que se respete y cumpla con la afectación que la ley prescribe que la Administración posee ciertos poderes sobre el administrado en orden a conducir su comportamiento a los intereses generales.

\footnotetext{
${ }^{45}$ Villar Palasí, José Luis (1950). "La actividad industrial del Estado en el Derecho Administrativo”. RAP, No 3, pp. 90 y 91.

46 Nieves Borrego, Julio (1963). "Estudio sistemático y consideración jurídico administrativa de la subvención”. Revista de Administración Pública, No 42, p. 29-30; Fernández Farreres (1983), p. 261.

${ }^{47}$ Fernández Farreres (1983), pp. 231-232.

${ }^{48}$ De la Riva (2004), p. 176. Véase García de Enterría, Eduardo y Fernández, Tomás Ramón (2006). Curso de derecho administrativo. Buenos Aires: La Ley, $1^{\text {a }}$ Edición de la 9a Edición española, T. II, p. 31.
} 
En este trabajo se distingue a la subvención de los llamados "subsidios". Coincidimos con FERNÁNDEZ ${ }^{49}$ con que deben excluirse del concepto estricto tales beneficios que, con carácter asistencial, no importan carga alguna. En este punto, la doctrina ha alcanzado algún nivel de acuerdo ${ }^{50}$. Los subsidios no buscan que el beneficiario alcance el interés general, sino más bien que éste salga de una situación de necesidad o carencia.

Compartimos con DE LA RIVA que conviene reservar para esta clase de ayudas la denominación de "subsidios" 51 , tanto por razones estrictamente gramaticales como por su empleo usual en nuestra legislación (v. gr. subsidio al consumo de electricidad -D.S. No 208 de 2005, Hacienda- subsidio al consumo de agua potable-D.S. No 195 de 1998, Hacienda-).

\subsection{Clasificación}

Una vez que se ha delimitado precisamente el concepto, a continuación expondremos brevemente algunas clasificaciones posibles de la subvención, atendiendo a los sujetos que intervienen, al objeto sobre el cual recae, al procedimiento en que se otorgan, a las cargas que traen aparejadas y, finalmente, según las materias subvencionadas.

No se trata de un simple ejercicio de enumeración, sino que se sigue minuciosamente los efectos jurídicos diversos que están presentes en uno u otro tipo de subvención.

\section{a. Según los sujetos}

En primer lugar, atendiendo a los sujetos que otorgan las subvenciones, puede distinguirse entre subvenciones otorgadas por las municipalidades y subvenciones otorgadas por otros OAE.

Las subvenciones municipales están reguladas en sus aspectos básicos, en el artículo $5^{\circ}$ de la LOCM. Se caracterizan por su dispersión normativa pues, toda vez que las municipalidades gozan de autonomía organizatoria y presupuestaria según la Constitución (artículos 119 y 120), cada municipio puede regularlas como estime conveniente.

\footnotetext{
${ }^{49}$ Fernández Farreres (1983), nota 214, p. 234. "Se excluyen todo un amplio conjunto de 'ayudas' que bajo los términos de 'auxilios', 'subsidios' e, incluso, 'subvenciones', la Administración otorga a determinados particulares en atención a la situación objetiva en la que se encuentran, con un claro y marcado carácter social, de ayudas y prestación a los sectores de la sociedad más necesitados”.

${ }^{50}$ De la Riva (2004), pp. 164-165. En el mismo sentido SÁnchez Morón, Miguel (2006). Derecho Administrativo. Parte General. Madrid: Tecnos, 2a Edición, p. 766.

${ }^{51}$ De la Riva, Ignacio (2004), p. 167. El uso de este término no es pacífico en la doctrina. Dan definiciones distintas de él Villar Ezcurra, José Luis (1999). Derecho Administrativo Especial. Madrid: Civitas, p. 122; y Maljar (1998), p. 292.
} 
Son una especie de ayuda destinada a personas jurídicas, públicas o privadas, sin fines de lucro, que colaboren directamente en el cumplimiento de las funciones del Municipio o bien a las corporaciones y fundaciones de las que formen parte (artículo $5^{\circ}$ letra g) y artículo 132 LOCM).

Las subvenciones se otorgan por el alcalde, con acuerdo del Concejo (artículo 65 letra g).

Existe un tope máximo para las subvenciones: no pueden exceder, en conjunto, al $7 \%$ del presupuesto municipal. Se exceptúan de este límite, por una parte, las subvenciones y aportes que las municipalidades destinen a las actividades de educación, de salud o de atención de menores que les hayan sido traspasadas en virtud de lo establecido en el D.F.L. No 1/3.063, cualquiera sea su forma de administración, ni las destinadas a los Cuerpos de Bomberos. Por otra parte, las subvenciones o aportes que las Municipalidades de Santiago, Vitacura, Providencia y Las Condes efectúen a la Corporación Cultural de la I. Municipalidad de Santiago, para el financiamiento de actividades de carácter cultural que beneficien a los habitantes de dichas comunas (artículo 5० letra g) LOCM).

En cambio, las subvenciones que otorgan otros OAE no gozan del mismo ámbito de autonomía y, a falta de atribución especial, se regulan en leyes y decretos supremos.

En segundo lugar, atendiendo a los sujetos que reciben las subvenciones, puede distinguirse entre las subvenciones a personas jurídicas sin fines de lucro y las demás.

La relevancia de esta distinción es que, conforme a la Ley No 19.862, las personas jurídicas receptoras de fondos públicos, que no persigan fines de lucro, deben ingresar a un registro especial, del que ya se hizo mención.

En cambio, los demás receptores de fondos públicos, sólo deben cumplir con las normas generales de transparencia de la Ley No 20.285.

\section{b. Segun el objeto}

Según el objeto sobre el que recae la subvención podemos distinguir entre subvenciones en dinero y subvenciones reales.

La mayor parte de las subvenciones reguladas por nuestra legislación son subvenciones en dinero. Es el caso típico. Eso significa que, por la percepción de la subvención el beneficiario adquiere el dominio del dinero, sin que ello signifique que las sumas pierdan su carácter afectado ni que se extinga la obligación de restitución en los casos de incumplimiento del fin de interés público involucrado.

Además, la legislación actual admite ciertos casos de subvenciones que se otorgan en bienes, incluso inmuebles. Por una parte, la Ley No 20.285 prevé que la subvención pueda consistir en dinero o en otra cosa; por otra parte, la Ley No 19.712 precisamente faculta a entregar como subvención bienes inmuebles en los cuales desarrollar actividades deportivas. 


\section{c. Según el procedimiento para otorgarlas}

Como se detallará más adelante, del estudio de la normativa vigente en materia de subvenciones es posible distinguir tres procedimientos típicos a través de los cuales se entregan las subvenciones: asignación reglada, mediante concursos públicos o asignación directa. En la próxima sección se analizan en detalle cada una de estas subvenciones.

\section{d. Según las cargas que imponen}

FERNÁNDEZ FARRERES identifica una clasificación de las subvenciones que atienden a los derechos constitucionales que son afectados por ellas. A su juicio, la intensidad que tiene el poder público para definir y poner requisitos a la actividad subvencionada es más débil en el caso que esa actividad esté amparada por derechos fundamentales.

"La subvención es una atribución patrimonial afectada en el sentido de que vincula al beneficiario a dar cumplido destino a lo percibido, según la finalidad material que se persiga con su otorgamiento. Finalidad que, como se ha visto, se limita a una doble posibilidad, de menor a mayor grado de intensidad: o bien posibilitando económicamente al beneficiario para que pueda cumplir la actividad o desarrollar la conducta propia, considerada, no obstante, por el ente otorgante y por el ordenamiento como de interés público -con libertad, por tanto, y sin sujeción a otros compromisos que el de hacer efectiva y actual esa actividad o conducta-, o bien induciendo al beneficiario, como consecuencia de la subvención, a la realización de una concreta y determinada conducta o actividad con arreglo a los objetivos que, aqui sí, fije el ente otorgante -con una mayor constricción-, por ende, de su libertad de acción, de actuación $\$ 2$.

Por ello, distingue entre subvenciones de actividad y subvenciones de resultado.

En cualquier caso, para el autor resulta imposible concebir una auténtica subvención sin al menos la carga de emplear la atribución patrimonial de qué consiste la subvención en la actividad para la que se otorgan, incluso cuando tal actividad consiste en el ejercicio de un derecho fundamental ${ }^{53}$.

\subsection{Naturaleza jurídica}

La doctrina ha debatido, en relación al carácter afectado de las subvenciones, sobre su naturaleza jurídica. Aunque hoy en día, casi se han abandonado las

\footnotetext{
${ }^{52}$ Fernández Farreres (1983), pp. 245-246.

${ }^{53}$ FernándeZ Farreres (1987), p. 75.
} 
explicaciones que recurren solamente a las categorías contractuales (NIEVES ${ }^{54}$ ) y han adquirido más aceptación las explicaciones "unilaterales" de la subvención (FERNÁNDEZ ${ }^{55}$ ). La verdad es que atendiendo al derecho positivo, es necesario mantener una posición escéptica: el legislador recurre indistintamente a medios unilaterales o contractuales.

Si bien no es posible adoptar un dogma sobre la naturaleza jurídica de la cual participan todas las subvenciones en el derecho nacional, sí es posible extraer consecuencias que tendrá en la práctica el empleo por la autoridad del instrumento contractual o unilateral.

Puede observarse que en nuestro ordenamiento generalmente se emplea la forma unilateral para el otorgamiento de las subvenciones, pero en no pocos casos se emplean "convenios" o contratos públicos y, aún en ciertos casos, se utilizan medios inequívocamente de derecho privado.

La elección por la vía contractual tiene en efecto consecuencias prácticas que lo distinguen del uso de actos administrativos unilaterales.

En primer lugar, cuando se utiliza la vía contractual se aplican reglas de probidad más estrictas. En ausencia de una habilitación especial, el funcionario respectivo tiene un deber disciplinario de adoptar el procedimiento contractual que asegure la libre concurrencia y objetividad (artículos 9o y 62 LOCBGAE).

En segundo lugar, porque el contrato o convenio puede incluir "sanciones" no expresamente previstas por la ley y que pueden ser aplicadas directamente por la Administración. Muchas veces es la misma norma subvencional la que autoriza que el contrato incluya tales cláusulas exorbitantes ${ }^{56}$. La necesidad de mantener el apego de la actividad subvencionada a los fines que justifican el otorgamiento del beneficio justifica también, en ausencia de una regla expresa, que las bases de convocatoria establezcan estas cláusulas, las que son, en todo caso, aceptadas por el beneficiario.

En tercer lugar, porque se utilizan igualmente medios de ejecución bilaterales del contrato como el recurso a cauciones de derecho privado o acciones judiciales previas a la ejecución administrativa. El empleo de formas contractuales para perfeccionar el otorgamiento de la subvención abre para la Administración el empleo no sólo de los medios tradicionales de poder público, sino que, además, modalidades de actividad típicas del derecho privado.

\footnotetext{
${ }^{54}$ Nieves Borrego, Julio (1963). "Estudio sistemático y consideración jurídico administrativa de la subvención”. Revista de Administración Pública, No 42, p. 28. En idéntico sentido Maljar (1998), pp. 296 y ss.

${ }^{55}$ Fernández Farreres (1983), p. 396.

${ }^{56}$ Véase artículo 48 D.S. No 65, Educación, Reglamento del Fondo Nacional de Desarrollo de la Cultura y las Artes, 25 de marzo de 2004; artículo 30 D.S. No 151, Educación, Reglamento del Fondo de Fomento Audiovisual, 12 de septiembre de 2005; artículo 23 D.S. No 187, Educación, Reglamento del Fondo para el Fomento de la Música Nacional, 25 de octubre de 2004.
} 


\section{RÉGIMEN JURÍDICO}

\subsection{Principios Constitucionales}

Se han identificado tres principios constitucionales que configuran la actividad de otorgamiento de subvenciones: el principio de legalidad, de igualdad y el de transparencia.

El principio de legalidad ha planteado una paradoja para la actividad subvencional. Se consideró históricamente que las mismas no estaban vinculadas a este principio, propio de los actos de gravamen. Sin embargo, en la Constitución chilena se previó expresamente la sujeción de las ayudas públicas a la reserva legal. Con todo, en su aplicación, el Tribunal Constitucional ha estimado que existen varias razones para flexibilizar esta reserva y permitir una amplia cabida a la colaboración reglamentaria ${ }^{57}$. En efecto, la reserva de ley debe moderarse por el hecho que las subvenciones no sólo producen -eventualmente- efectos negativos en la libre competencia o la igualdad en el trato económico, sino que también son, en ciertos casos, el presupuesto necesario para el ejercicio de derechos sociales reconocidos por la propia Constitución como el derecho a vivir en un medio ambiente libre de contaminación, la protección de la salud y el acceso a la educación gratuita ${ }^{58}$.

$\mathrm{Al}$ respecto resulta muy reveladora la sentencia del Tribunal Constitucional, de 26 de junio de 2001, donde se expresa que:

"Si bien las normas legales en que se funda el D.S. No 20 en estudio no cumplen a cabalidad con los requisitos de 'determinación' de los derechos que podrán ser afectados y 'especificidad' de las medidas que se autorizan para llevar a cabo tal objetivo que la Carta Fundamental exige a fin de restringir o limitar los derechos comprometidos en el caso sub-lite, esta Magistratura ha llegado a la convicción que tales requisitos resultan aceptables en este caso y sólo para aplicación a él. Ello, en consideración de que la medida de restricción vehicular, establecida con el carácter de excepcional y en situaciones de emergencia y pre-emergencia ambiental obedece al cumplimiento de un deber del Estado consagrado en el inciso primero del número $8^{\circ}$ del artículo 19 de la Constitución y está destinada a proteger el derecho más preciado de los asegurados por nuestro Código Politico, cual es la vida humana y la integridad física y psíquica de las personas. Obrar de otra manera y declarar la inconstitucionalidad del D.S. No 20 podría generar una vulneración de mayor entidad de nuestra Carta Fundamental, al no permitir la ejecución de una restricción de derechos que, atendida la situación ambiental existente, resulta necesaria para proteger la salud de la población y, por ende,

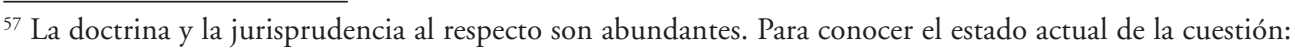
Carmona Santander, Carlos (2010). "El artículo 93 No 16 de la Constitución: estado de la cuestión y proyecciones”. Revista de Derecho Público, No 72, pp. 52 y ss., y la completa doctrina y jurisprudencia ahí citada.

${ }^{58}$ En el mismo sentido Gimeno Feliú (2005), p. 944.
} 
lograr el bien común, finalidad primordial del Estado, establecida en el artículo $1^{\circ}$ de la Constitución" (C. 46º, STC Rol No 325).

Este criterio ha sido reafirmado por el Tribunal Constitucional en sentencia de 19 de junio de 2007:

"Que la legislación sobre subvenciones es un medio -entre otros posibles-que el Estado utiliza para cumplir el deber que la Constitución le impone en el artículo 19 $N^{o} 10^{\circ}$, incisos cuarto y quinto, de concurrir a financiar un sistema gratuito que asegure el acceso de toda la población al segundo nivel de la educación parvularia y a los niveles básico y medio de educación, como también el deber del artículo 10, inciso quinto, de asegurar el derecho de las personas a participar con igualdad de oportunidades en la vida nacional. A través de la subvención se procura que todas las personas gocen efectivamente del derecho a la educación, pero las normas que fijan su monto, clases y requisitos para impetrarla, no tienen el carácter de una ley que regule un derecho constitucional y, por tal razón, ha sido posible que esa legislación esté contenida en un decreto con fuerza de ley, denominado usualmente Ley de Subvenciones, lo que no sería constitucionalmente procedente si la misma tuviese el carácter de ley regulatoria de un derecho constitucional, ya que, atendido lo dispuesto en el artículo 64, inciso segundo, de la Carta Fundamental, se prohibe delegar facultades legislativas al Presidente de la República en materias comprendidas en las garantías constitucionales;" (C. 8, STC Rol No 771).

"Que, al no contener en su texto la Constitución Política una disposición especifica que fije el ámbito de la legislación sobre subvenciones, en el caso de esta ley ésta encuentra su fundamento principal en el $N^{\circ} 20$ del artículo 63 de la Carta Fundamental que señala como materia de ley: 'Toda otra norma de carácter general y obligatoria que estatuya las bases esenciales de un ordenamiento jurídico'. Estas leyes son las que, en ocasiones, se denominan leyes de bases, toda vez que el sistema de fuentes del derecho contemplado en la Constitución permite aprobar sobre cualquier asunto en que no esté vedada la intervención del legislador, pero sólo en sus aspectos fundamentales" (C. 10, STC Rol No 771).

Fuera de lo anterior, para el Tribunal la reserva de ley se encuentra moderada aún más tratándose de la ejecución presupuestaria, de la cual la actividad subvencional es una rama más. A juicio del tribunal, la importancia del presupuesto hace que deba dotarse al Presidente de todos los medios necesarios para el cumplimiento del objetivo final del gasto público. (C. 18º, STC Rol No 254, 26 de abril de 1997).

En segundo lugar, resulta obvio que las subvenciones representan una excepción al principio general de igualdad; beneficiar a una actividad significa seleccionarla y dejar fuera a las demás. La Constitución permite esa selección siempre que no sea "arbitraria".

La Constitución prevé que la ley puede beneficiar algún "sector", "actividad" o "zona geográfica”. La doctrina y la jurisprudencia constitucionales entienden que:

“con la expresión 'sector' se alude a una parte de la actividad productiva o económica del pais. Ejemplo, los agricultores, los acuicultores. Con la voz 'actividad' se refiere la 
Constitución a emprendimientos determinados, con caracteristicas operativas especificas; por ejemplo: los productores lecheros. Finalmente, con la expresión 'zona geográfica' se alude al desarrollo económico que se lleva a cabo en un lugar del territorio nacional, que puede o no corresponder a la división político administrativa del pais. En todo caso, el legislador, cuando establezca el beneficio o el gravamen, debe individualizar claramente el sector, actividad o zona geográfica" (STC Rol No 1295, C. 92. En el mismo sentido se expresa Humberto Nogueira ${ }^{59}$ ).

En tercer lugar, un nuevo principio constitucional que tiene gran importancia en materia de subvenciones - toda vez que son un gasto público- es la transparencia. Este principio tiene un reciente reconocimiento constitucional y ha sido elevado por la jurisprudencia a un verdadero principio rector del gasto público. Además, ha sido desarrollado por dos leyes esenciales: la Ley No 19.862, que somete a las personas jurídicas beneficiarias a un registro habilitante y la Ley No 20.285, sobre Transparencia y Acceso a la Información Pública, que faculta a conocer aquella información elaborada con fondos públicos.

\subsection{Procedimiento para otorgarlas}

Como se adelantó, el legislador chileno emplea tres tipos de procedimientos para asignar subvenciones. Según su objetividad.

\section{a. Asignación reglada}

Ante todo, es posible identificar ciertas subvenciones que se asignan a través de un procedimiento reglado en que se otorgan, simplemente, a todos los sujetos que cuenten con cierto título administrativo previo (concesión, autorización, registro, etc.). En estos casos, la Administración no elige al destinatario, sino que comprobada la calidad especial que la ley exige, se otorga a todos. Son ejemplos de esta forma de asignación la subvención a los "sostenedores" de establecimientos educacionales (artículo 6, D.F.L. № 2, de 1998, Educación), la subvención escolar a alumnos prioritarios (artículo $1^{\circ}$ Ley No 20.248 y artículo $1^{\circ}$ D.S. No 235 de 2008, Educación), el aporte fiscal directo e indirecto (Ley No 11.575), la bonificación a los predios de aptitud preferentemente forestal (artículo 12 D.L. No 2565), el subsidio para el transporte público remunerado (Ley No 20.378) y el financiamiento de las campañas electorales (artículos 13 bis y 14, Ley No 19.884).

\section{b. Asignación mediante concurso público}

Luego, es posible encontrar subvenciones que se otorgan previo concurso público. El concurso sigue un procedimiento típico (publicidad de las bases,

\footnotetext{
59 Nogueira Alcalá, Humberto (2010). Derechos fundamentales y garantías constitucionales. Santiago: Librotecnia, T. IV, p. 161.
} 
convocatoria, postulación, evaluación, adjudicación, publicidad e impugnación), pero hay dos modelos de otorgamiento.

Por una parte existen los "Fondos Concursables", que se caracterizan por el hecho de formalizarse en convenios de ejecución, que se suscriben entre el órgano administrativo y el beneficiario. Son ejemplos de este tipo de procedimiento el Fondo Nacional de Desarrollo Cultural y las Artes (artículo 28 Ley No 19.981), el Fondo de Fomento Audiovisual (artículos $8^{\circ}$ y $9^{\circ}$ Ley No 19.891), el Fondo para el Fomento de la Música Nacional (artículo 50 Ley No 19.928), el Fondo Nacional para el Fomento del Deporte (artículo 41 Ley No 19.712), el Programa de Apoyo al Transporte Regional (artículo 5o, letra a) de la Ley y D.S. No 4, de 2010, Transportes y Telecomunicaciones), el Fondo Nacional de Desarrollo Científico y Tecnológico (D.F.L. No 33 de 1981, Educación), el Fondo de Desarrollo de las Telecomunicaciones (artículos 28 F y 28 G, Ley No 19.724 y D.S. No 353, de 2001, Transportes y Telecomunicaciones), el Fondo CNTV y el Fondo "Antenas" (artículos 12 b) y 13 bis, Ley No 18.838), el Fondo Mixto de Apoyo Social (artículos 11 y siguientes del D.S. No 266 de 2004, Planificación), el Fondo de Capacitación y Empleo (artículos 12 y 47 Ley No 19.518), el Fondo Concursable para Asociaciones de Consumidores (artículos 11 a 17 D.S. No 37 de 2005, Economía) y el Fondo de Fortalecimiento de las Organizaciones de Interés Público (artículos 21 y siguientes Ley No 20.500).

Por otra parte, existen los "subsidios" mediante títulos transferibles, que se formalizan mediante la entrega de un título o "certificado" que se hace transferible para el beneficiario, es decir, que se transforma en comerciable. Son ejemplos de este procedimiento de asignación el llamado "subsidio" habitacional (artículo $1^{\circ}$ letra e), D.S. No 40 de 2004, Vivienda), el Fondo Solidario de Vivienda (D.S. No 174 de 2005, Vivienda), el sistema de subsidio habitacional rural (D.S. No 145 de 2007, Vivienda) y el subsidio para el deporte (artículo 51 Ley No 19.712).

\section{c. Asignación directa}

Finalmente, existen también subvenciones que se otorgan directamente, es decir, sin procedimiento reglado de selección. En estos casos, la ley solamente atribuye ciertos fondos para que sean empleados en algún fin. Lo anterior no significa que estén exentos de control, sino que se acentúa el control político: por el Congreso $^{60}$, en el caso de las subvenciones previstas por el Presupuesto Nacional, y por el Concejo Municipal, en el caso de las subvenciones municipales.

\footnotetext{
${ }^{60}$ Eso es lo que ocurre, por ejemplo, con la Ley de Presupuestos del Sector Público para el año 2011 partida 50 , capítulo 01 , programa 02 , subtítulo 24 , ítem 01002 . La glosa respectiva señala requisitos formales mínimos y medios de control político de la subvención: "Sólo se podrán otorgar a personas jurídicas del sector privado que no persigan fines de lucro. La Dirección de Presupuestos elaborará trimestralmente una nómina de los decretos totalmente tramitados en el período, que dispongan subvenciones con cargo a esta asignación, identificando sus destinatarios y finalidad, la que remitirá a las Comisiones de Hacienda del
} 
También opera este modo de asignación directa cuando en una subvención que se otorga normalmente por concurso público, excepcionalmente la ley o el reglamento reservan un espacio para la asignación directa. Así ocurre con el Fondo de Desarrollo Indígena, el Fondo de Protección Ambiental, el Fondo de Fomento Audiovisual, el Fondo de Fomento de la Música Nacional, el Fondo de Fomento del Deporte y el Fondo de conservación, recuperación y manejo sustentable del bosque nativo.

\subsection{Situación jurídica del beneficiario}

Como se ha insistido, la subvención constituye una relación entre dos sujetos, el otorgante y el beneficiario.

Este último tiene el deber de realizar la actividad subvencionada. Si no lo hace, la subvención pierde eficacia y, como se verá, puede ser caducada. Dicho directamente, la obligación de pago, la exigibilidad de la obligación económica, queda pendiente del cumplimiento por el beneficiario de la correspondiente carga jurídica a que se supeditó el acceso efectivo al beneficio concedido. Frente a ello, "el incumplimiento de la carga jurídica determina de un modo natural la no exigibilidad de la subvención o, en el supuesto de que se hubiera ya pagado..., la devolución íntegra de la suma percibida" ${ }^{61}$.

Sin embargo, la ley no es completamente libre de establecer los deberes a que debe someterse el beneficiario. Cuando la subvención incide en derechos fundamentales de libertad, debe respetar el contenido esencial de los derechos y la proporcionalidad.

Por eso, debe rechazarse la posición de Soto Velasco quien sostiene que habría ciertas "condiciones" inconstitucionales en los actos administrativos favorables (como autorizaciones o subvenciones). El autor utiliza la noción de "condiciones inconstitucionales", originada en un puñado de fallos de la Corte Suprema norteamericana, para sostener que "el Estado no podría exigir que el receptor de un beneficio público renuncie a alguno de sus derechos fundamentales. Esto, aun cuando el Estado mismo no esté en la obligación de conceder ese beneficio" 62 .

La posición de Sebastián SoTo debe ser rechazada, desde ya, porque la doctrina de las condiciones inconstitucionales no es aceptada por la jurisprudencia

\footnotetext{
Senado y de la Cámara de Diputados dentro de los 15 días siguientes al de vencimiento del respectivo trimestre". El Tribunal Constitucional ha validado estos deberes, fundándose en el principio de transparencia (Sentencia Tribunal Constitucional, Rol No 1867, C. $30^{\circ}$ ).

${ }^{61}$ Fernández Farreres (1983), p. 424.

${ }^{62}$ Soto Velasco, Sebastián (2009). "Subsidios, permisos y condiciones: la doctrina de las condiciones inconstitucionales en Estados Unidos y su aplicación en Chile”. Revista Chilena de Derecho, Vol. 36, p. 116.
} 
más importante y ni siquiera tiene coherencia entre los autores que la defienden ${ }^{63}$. En consecuencia, pasando por alto las diferencias entre los sistemas, ni siquiera ahí donde ha sido ideada la noción tiene una consistencia que la haga digna de imitación.

En segundo lugar, el autor omite completamente la diferencia entre actos de gravamen y actos favorables, es decir, entre aquellos que limitan derechos (como las sanciones) y aquellos que amplían la esfera subjetiva del administrado. Tanto las subvenciones y autorizaciones (o subsidios y permisos como él los llama) pertenecen a la categoría de actos favorables. Entre subvención y sanción no puede aplicarse un criterio de analogía como pretende Sото $^{64}$.

En tercer lugar, incluso si se acepta la tesis central del autor, esto es, que el Estado tiene límites para imponer condiciones a la hora de otorgar subvenciones y autorizaciones, la solución propuesta no entrega ningún criterio que sea distinto al principio de proporcionalidad.

En efecto, el Tribunal Constitucional emplea al menos dos test para evaluar la legitimidad de las cargas o deberes que impone el Estado. Por una parte, el test de proporcionalidad de Alexy, según el cual debe revisarse entonces si las limitaciones que establece la norma legal en examen se encuentran suficientemente determinadas por la ley y si están razonablemente justificadas; esto es, si persiguen un fin lícito, resultan idóneas para alcanzarlo y si la restricción que imponen puede estimarse proporcional al logro de esos fines lícitos que la justifican (STC Rol No 1345).

Por otra parte, ha propuesto un test específico para la arbitrariedad legislativa, conforme al cual hay que buscar la justificación, el motivo que explica y funda la medida. No se trata con ello de que exista una razón que convenza o persuada a todos. Lo relevante es que esa razón exista, sea suficiente y coherente con la decisión, y no sea ilegítima; se trata de justificar, no de obligar a creer en esas razones (STC Rol No 1295).

Por último, en su reciente sentencia de 2009, el Tribunal Constitucional ha aceptado que es consustancial al concepto de subvención su carácter afectado a un determinado fin, lo que implica la imposición de condiciones para su goce:

"Al otorgar estos beneficios, el legislador puede perfectamente establecer condiciones o requisitos para su obtención o para su mantención, para lograr la finalidad pública que se busca obtener con la transferencia. Estas transferencias no son un regalo, sino una donación modal o condicionada al cumplimiento de determinados fines para recibirlos $y$ al logro de ciertos resultados que se estiman valiosos. Ello implica, en ciertos casos, restricciones de derechos" (STC Rol No 1295, C. 90).

63 "Ni la Corte Suprema de Estados Unidos ni la academia de ese mismo país han logrado elaborar una convincente aplicación de la doctrina a los casos en que esta es aplicable", Sото VelasCo (2009), p. 138.

${ }^{64}$ Soto Velasco (2009), p. 120. 


\subsection{Situación jurídica del otorgante}

\section{a. Obligación de pagar la subvención y posibilidad de modificarla}

En el otro extremo de la relación subvencional se encuentra a la Administración otorgante. Cabe precisar que, si bien la decisión de establecer o no una subvención es completamente discrecional, una vez que se constituye esta relación jurídica, se genera para el particular un derecho subjetivo que no puede ser desconocido por la Administración. Luego, la obligación primordial que asume la Administración es pagar la subvención, siempre que haya logrado comprobar que el particular efectivamente destinó los fondos a los fines para los cuales se entregaron.

Se ha dicho antes que la Administración tiene amplias facultades para establecer o eliminar, discrecionalmente, las subvenciones. Por lo tanto, puede concluirse que, cuando se han otorgado subvenciones por un determinado período de tiempo ${ }^{65}$, o en virtud de otras circunstancias que desaparecen durante la vigencia del sistema ${ }^{66}$, no existe un derecho de parte de los beneficiarios actuales para exigir el mantenimiento de tales situaciones: "la Administración puede cancelar posteriormente el sistema subvencional establecido. Y ello, bien sea modificando la ordenación jurídica que al efecto lo pudo establecer, bien simplemente, dejándolo sin efectividad práctica: basta a tal fin no establecer la consignación presupuestaria obligada" ${ }^{67}$.

Luego, con el acto de otorgamiento se origina la relación subvencional entre la Administración otorgante y el particular beneficiario. En virtud de esta relación la Administración otorgante adquiere una verdadera obligación de pago. Se encuentra jurídicamente obligada a satisfacer el pago de la subvención en favor del beneficiario ${ }^{68-69}$.

En todo caso, la eficacia del acto, es decir, el goce pleno de sus efectos dependerá del hecho que el beneficiario cumpla efectivamente con las cargas impuestas y que la Administración acredite dicha circunstancia satisfactoriamente. Fernández expone esta circunstancia del siguiente modo:

"De ese mismo acto de otorgamiento si que surge, en cambio, una obligación jurídica a cargo del ente administrativo otorgante, que no podrá eximirse del cumplimiento de la misma si el beneficiario cumple la correspondiente carga jurídica. El acto de otorgamiento de la subvención se muestra, por tanto, como un acto verdaderamente

\footnotetext{
${ }^{65}$ Es lo que ocurre con el fomento para el riego. Así, el fomento a la inversión privada en obras de riego y drenaje ha sido objeto de numerosas prórrogas desde su inicio en 1985, la última de las cuales es de 2010, extinguiéndose en doce años. Igual cosa ocurre con el fomento forestal, o los subsidios al transporte público de pasajeros.

${ }^{66}$ Es lo que ocurre con el subsidio a la vivienda para los damnificados por el terremoto de Concepción de 2010.

${ }^{67}$ Martín-Retortillo Baquer (1988), pp. 483-484.

${ }^{68}$ Santamaría Pastor (2006), p. 366.

${ }^{69}$ СамасHо (2007), p. 562.
} 
singular, ya que determinando el nacimiento de una obligación jurídica para la Administración supedita su eficacia, no obstante, al hecho de que el titular del derecho de crédito correspondiente -beneficiario de la subvención-cumpla la carga jurídica en que se resume el carácter afectado de toda subvención"

\section{b. Potestades de control inherentes a la subvención}

Para lograr que la subvención sea totalmente eficaz, la Administración goza de potestades de control y dirección sobre el particular beneficiario. Al respecto, hemos identificado dos potestades que son inherentes a la relación subvencional, es decir, que se poseen como consecuencia lógica de la existencia de la potestad, sin que sea necesario que la ley las prevea expresamente ${ }^{71-72}$.

Por una parte, la Administración goza de la facultad de comprobar el cumplimiento de las cargas que justifican la subvención. Es decir, dado que en las cargas se materializa la afectación de la actividad a un interés público, la Administración debe, ante todo, tener los medios para verificar que se les ha dado cumplimiento.

$\mathrm{Al}$ respecto, la ley ha empleado diferentes modalidades, donde destaca la potestad inspectiva. Cabe recordar que las potestades de inspección, investigación o supervisión habilitan a la Administración para llevar a cabo funciones de comprobación o constatación de la legalidad. En sí mismas, no tienen naturaleza ablatoria, sino sólo preparatoria de la actividad administrativa. Además, el particular está obligado a colaborar con la Administración para otorgarle la información requerida ${ }^{73}$.

Por otra parte, la Administración tiene siempre la facultad de, ante incumplimientos graves, declarar la caducidad de la subvención. La caducidad es una consecuencia jurídica necesaria de aquellos actos administrativos favorables, que están acompañados del deber de realizar cierta conducta. Por lo tanto, si no se realiza la conducta, el derecho a percibir la subvención se extingue, el gasto público carecerá de causa.

Se ha dicho que el fundamento de la caducidad radica en que "este es uno de los casos especificos donde debe primar el interés público por sobre la prerrogativas individuales, ya que se está en presencia de actos unilaterales de voluntad de la administración, que, privando del ejercicio de determinados bienes escasos a otros interesados, ha reconocido, en cambio, estas franquicias respecto de quienes pasaron a ser sus

\footnotetext{
${ }^{70}$ Fernández Farreres (1983), p. 442.

71 García de Enterría, Eduardo y Fernández, Tomás Ramón (2004). Curso de Derecho Administrativo. Buenos Aires: La Ley, $1^{\text {a }}$ Edición de la 12a Edición española, T. I, p. 456.

72 García de Enterría y Fernández (2004), p. 457.

${ }^{73}$ Bermejo Vera, José (2006). "Acción administrativa y potestades". En: Derecho Administrativo. Parte Especial. Madrid: Civitas, 6a Edición, p. 127. En el mismo sentido Rivero OrtegA, Ricardo (2000). El Estado vigilante. Madrid: Tecnos, pp. 60 y 67; García UReTA, Agustín (2006). La potestad inspectora de las administraciones públicas. Madrid: Marcial Pons, p. 28.
} 
titulares. Ahora bien, esta titularidad representa un privilegio que ciertamente queda sujeto a determinadas cargas impuestas por el interés general de la colectividad. El incumplimiento de ellas dentro de los términos especificados de modo explícito, tanto en la ley como en el acto individual mismo, apareja la extinción, de pleno derecho, de las facultades conferidas por una decisión que sin duda era de privilegio"/4.

La caducidad ha recibido una interesante atención por la doctrina latinoamericana. Sin embargo, sus contornos resultan bastante difusos.

En primer lugar, la caducidad opera siempre sólo respecto de actos administrativos de naturaleza "mixta", o sea, que son al mismo tiempo positivos y negativos. Debe entenderse que son actos que sujetan el goce efectivo de sus efectos favorables al cumplimiento de un "deber"75.

Aunque gran parte de la doctrina sostiene que son actos sujetos a "obligaciones"76, creemos que no se trata de "obligaciones", sino de deberes o cargas". Ello, porque es inherente a la obligación que el interés que satisface pertenece exclusivamente al acreedor. En cambio, tratándose de las cargas o deberes el interés puede ser el del propio sujeto pasivo o el interés público.

Piccinni afirma que la caducidad exige siempre la presencia de un plazo como elemento adicional al incumplimiento del beneficiario ${ }^{78}$. Creemos que siendo efectiva su afirmación, es posible que existan plazos tácitos, tal como en el derecho común ${ }^{79}$.

Para Soria, es necesario que el incumplimiento sea "culpable", en sentido amplio, es decir, atribuible o imputable a la persona que ha de ser desalojada de su situación subjetiva ${ }^{80}$.

\footnotetext{
${ }^{74}$ Madariaga Gutiérrez, Mónica (1993). Seguridad juridica y Administración Pública en el siglo XXI. Santiago. Editorial Jurídica de Chile, 2a Edición, p. 105.

75 "La caducidad supone que el acto que se extingue fundamentalmente concedía un derecho, creando al mismo tiempo ciertos deberes: es el incumplimiento de los segundos lo que lleva a la extinción del primero y con ello del acto todo". (Gordillo, Agustín (2007). Tratado de Derecho Administrativo. Buenos Aires: F.D.A., 9a Edición, T. III, p. XIII-18).

${ }^{76}$ Piccinni García, Doris (1968). Teoría del decaimiento de los actos administrativos. Santiago: Editorial Jurídica de Chile, pp. 25-29.; Caldera Delgado, Hugo (1979). Manual de Derecho Administrativo. Santiago: Editorial Jurídica de Chile, pp. 212-213; Madariaga Gutiérrez (1993), pp. 103 y ss.; Silva Cimma, Enrique (1995). Derecho Administrativo chileno y comparado. Actos, contratos y bienes. Santiago: Editorial Jurídica de Chile, 4a Edición, p. 153; SAYAgués Lazo, Enrique (2002). Tratado de Derecho Administrativo. Montevideo: FCU, 8a Edición, T. I, p. 519; Gordillo (2007), pp. XIII-17 a 19.

${ }^{77}$ Ver supra capítulo 1. Comadira, Julio y Escola, Héctor (2006). Derecho Administrativo Argentino. México D.F.: Porrúa, pp. 397 y 398; y Moraga Klenner, Claudio (2007). "La actividad formal de la Administración del Estado". En: Derecho Administrativo Chileno, Pantoja BauzÁ, Rolando (Coord.), México D.F.: Porrúa, pp. 309-310. En el mismo sentido que se sostiene acá, véase SoRIA, Daniel Fernando (2002). "La caducidad del acto administrativo". En: Acto administrativo y procedimiento, Facultad de Derecho Universidad Austral, Buenos Aires: Ediciones RAP, p. 282.

${ }^{78}$ Piccinni GarCÍa (1968), p. 27.

${ }^{79}$ Madariaga Gutiérrez (1993), p. 104.

${ }^{80}$ SORIA (2002), p. 283.
} 
En segundo lugar, es necesario que el incumplimiento sea de una entidad grave, pues la Administración goza de otros medios menos gravosos para dirigir y controlar la conducta del interesado como aplicar multas $\mathrm{u}$ otras sanciones ${ }^{81}$.

Soria sostiene que es necesario "reconocerle a la Administración un cierto margen de maniobra para apreciar la razonabilidad de la medida”, lo que no sólo protege los derechos del beneficiario sino que es coherente con una mejor satisfacción de los intereses generales's2.

En tercer lugar, la caducidad debe ser declarada por la Administración ${ }^{83}$. Esta declaración produce efectos hacia el futuro, no retroactivos. Antes de proceder a la declaración es necesario que la Administración le intime al interesado su retardo. Por esta razón se ha señalado que es necesario que se notifique formalmente al beneficiario señalándole un plazo para cumplir, emplazándolo ${ }^{84}$.

\section{c. Potestades de control que requieren de atribución expresa}

Además de lo anterior, la ley dota expresamente de otras potestades a la Administración en orden a dirigir la conducta del sujeto beneficiario.

Entre estas potestades destaca la potestad sancionatoria, cuyo estudio merece un trabajo separado. Para efectos de este artículo, basta señalar que el régimen sustantivo de infracciones y sanciones requerirá siempre una definición legal previa, con la densidad normativa suficiente (en sus elementos esenciales) para que pueda intervenir la potestad reglamentaria en su desarrollo. En lo que dice relación con el procedimiento que tiene aplicación, ante el silencio de las leyes sectoriales, se aplica la LBPA, particularmente los derechos que le otorga al interesado. Tal régimen es el que emana de la interpretación consistente del Tribunal Constitucional que ha definido las garantías básicas de las sanciones y procedimiento sancionador ${ }^{85}$.

\footnotetext{
${ }^{81}$ Sayagués Lazo (2002), p. 519; Gordillo (2007), p. XIII-19.

82 SORIA (2002), p. 285.

${ }^{83}$ Piccinni García (1968), p. 27.

${ }^{84}$ Sayagués Lazo (2002), p. 519; Gordillo (2007), p. XIII-19.

${ }^{85}$ La interpretación del Tribunal Constitucional puede sintetizarse brevemente como sigue: la sanción administrativa es legítima porque es un acto administrativo (Sentencia Tribunal Constitucional, Rol No 124, C. $17^{\circ}$ y $18^{\circ}$ ); permite asegurar el funcionamiento de un servicio público (Sentencia Tribunal Constitucional, Rol No 287, C. 7o); la ley debe prever un debido proceso para la aplicación de las sanciones (Sentencia

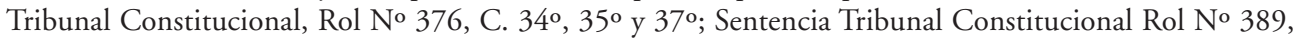
C. $33^{\circ}, 34^{\circ}$ y $36^{\circ}$; Sentencia Tribunal Constitucional, Rol No 437, C. $16^{\circ}$ y $17 \circ$ ); también tratándose de las sanciones disciplinarias (Sentencia Tribunal Constitucional, Rol No 747, C. 5\%); el reglamento puede complementar este procedimiento (Sentencia Tribunal Constitucional, Rol No 388, C. $22^{\circ}$ y $28^{\circ}$ ); la ley debe establecer un órgano imparcial que aplique la sanción (Sentencia Tribunal Constitucional, Rol No 783, C. $11^{\circ}$ ); el derecho administrativo sancionador es una manifestación de la potestad punitiva del Estado, por lo tanto, se le aplican los mismos principios que en el derecho penal (Sentencia Tribunal Constitucional, Rol No 244, C. 9º); sólo la ley puede establecer las conductas ilícitas y la sanción aplicable (Sentencia Tribunal Constitucional, Rol № 244, C. $12^{\circ}$ y $14^{\circ}$ ); el principio de legalidad no impide la colaboración reglamentaria en materia (Sentencia Tribunal Constitucional, Rol No 480, C. $15^{\circ}$ y $17^{\circ}$ ); los principios
} 


\section{CONClusiones}

La gran dispersión normativa que caracteriza a nuestro derecho administrativo actual no es un obstáculo para la investigación dogmática de sus instituciones. Este trabajo es una demostración de ello pues, observándose un fenómeno jurídico muy heterogéneo, se han entregado un verdadero modelo de regulación.

En efecto, de lo expuesto podemos concluir que nuestro legislador utiliza un modelo de subvención que se adapta correctamente a la conceptualización que se hace de ella en el derecho español y argentino.

En consecuencia, la subvención está esencialmente afectada o vinculada a un interés público que el particular beneficiario se encuentra obligado a realizar.

La Administración, por tanto, se encuentra obligada a pagar la subvención sólo en cuanto esa actividad de interés público ha sido realizada. Es por ello que tiene la potestad de comprobar su cumplimiento, así como caducar la subvención cuando ha existido una infracción grave.

limitadores de la potestad punitiva del Estado no son aplicables sin más a las sanciones administrativas (Sentencia Tribunal Constitucional, Rol No 747, C. 22\%); la exigencia de la consignación judicial previa es siempre una afectación intolerable al acceso a la justicia (Sentencia Tribunal Constitucional, Rol No 946, C. $33^{\circ}$ ). Una síntesis de este desarrollo jurisprudencial en Sentencia Tribunal Constitucional, Rol No 1413. 


\section{BiBLIOGRAFÍA CITADA}

AmunÁtegui, Domingo (1907). Tratado Jeneral de Derecho Administrativo. Santiago.

Bermejo Vera, José (2006). "Acción administrativa y potestades”. En: Derecho Administrativo. Parte Especial. Madrid: Civitas, $6^{a}$ Edición.

Bermúdez Soto, Jorge (2010). Derecho Administrativo General. Santiago: AbeledoPerrot LegalPublishing.

BüCHI Buc, Hernán (1993). La transformación económica de Chile. Del estatismo a la libertad económica. Bogotá: Editorial Norma.

Caldera Delgado, Hugo (1979). Manual de Derecho Administrativo. Santiago: Editorial Jurídica de Chile.

Camacho Cepeda, Gladys (2010). Actividad sustancial de la Administración. Santiago: Abeledo-Perrot LegalPublishing.

Carmona Santander, Carlos (2010). "El artículo 93 No 16 de la Constitución: estado de la cuestión y proyecciones". Revista de Derecho Público, No 72.

Cassagne, Juan Carlos (2006). Derecho Administrativo. Buenos Aires: LexisNexis, 7a Edición, T. II.

Cepal (1954). Antecedentes sobre el desarrollo de la economía chilena. 1925-1952. Santiago: Editorial del Pacífico.

Comadira, Julio y Escola, Héctor (2006). Derecho Administrativo Argentino. México D.F.: Porrúa.

Correa SutiL, Sofía et al. (2001). Historia del siglo XX chileno. Santiago: Editorial Sudamericana.

Daniel Argandoña, Manuel (1960). Derecho Administrativo. Santiago: Edugal, T. I.

De la Riva, Ignacio (2004). Ayudas Públicas. Buenos Aires: Editorial Hammurabi.

Eyzaguirre, Jaime (1959). Historia del Derecho. Santiago: Editorial Universitaria.

Fazio, Hugo y Parada, Magali (2010). Veinte años de política económica de la Concertación. Santiago: Lom Ediciones.

FERNÁNDEZ FARRERES, Germán (1983). La subvención: concepto y régimen jurídico. Madrid: IEF.

Fernández Farreres, Germán (1987). "De nuevo sobre la subvención y su régimen jurídico en el derecho español”. Revista de Administración Pública, No 113.

Fernández Farreres, Germán (2005). "Subvenciones”. En: Diccionario de Derecho Administrativo, MuÑoz Machado, Santiago (Dir.), Madrid: Editorial Iustel, T. II.

Figueroa, María Angélica (1980). "El Tribunal del Consulado de Chile y la política de fomento económico de los Borbones". En: V Congreso del Instituto 
Internacional de Historia del Derecho Indiano: realizado en Quito-Guayaquil, T. II, pp. 187-206.

García de Enterría, Eduardo y Fernández, Tomás Ramón (2004). Curso de Derecho Administrativo. Buenos Aires: La Ley, $1^{\text {a }}$ Edición de la 12a Edición española, T. I.

García de Enterría, Eduardo y Fernández, Tomás Ramón (2006). Curso de derecho administrativo. Buenos Aires: La Ley, $1^{\text {a }}$ Edición de la 9a Edición española, T. II.

García Ureta, Agustín (2006). La potestad inspectora de las administraciones públicas. Madrid: Marcial Pons.

Gimeno Feliú, José María (2005). "La técnica de fomento del desarrollo económico: la subvención”. En: Derecho administrativo. Parte especial, Bermejo Vera, José (Dir.), Madrid: Thomson-Civitas, 6a Edición.

Gordillo, Agustín (2007). Tratado de Derecho Administrativo. Buenos Aires: F.D.A., 9a Edición, T. III.

Iribarren, Juan Antonio (1935). Lecciones de Derecho Administrativo. Santiago: Nascimento.

Jocelyn-Holt Letelier, Alfredo (2009). La independencia de Chile. Tradición, modernización y mito. Santiago: Random House Mondadori.

Jordana de Pozas, Luis (1949). "Ensayo de una teoría del fomento en el derecho administrativo". Revista de Estudios Políticos, No 48.

Letelier Madariaga, Valentín (1904). Apuntaciones de Derecho Administrativo. Santiago.

López MuÑız, José Luis (1989). "La actividad administrativa dispensadora de ayudas y recompensas: una alternativa conceptual al fomento en la teoría de los modos de acción de la Administración Pública”. En: Libro homenaje al profesor José Luis Villar Palasí, Gómez-Ferrer Morant, Rafael (Coord.), Madrid: Civitas.

Madariaga Gutiérrez, Mónica (1993). Seguridad jurídica y Administración Pública en el siglo XXI. Santiago. Editorial Jurídica de Chile, 2a Edición.

MALJAR, Daniel (1998). Intervención del Estado en la prestación de servicios públicos. Buenos Aires: Editorial Hammurabi.

Martín-Retortillo Baquer, Sebastián (1988). Derecho Administrativo Económico. Madrid: La Ley, T. I.

Merino, Ernesto (1936). Derecho Administrativo. Santiago: Imprenta Universitaria.

Ministerio Secretaría General de la Presidencia (2000). Doctrina Constitucional del Presidente Eduardo Frei.

Ministerio Secretaría General de la Presidencia (2010). Doctrina Constitucional del Presidente Ricardo Lagos. 
Moraga Klenner, Claudio (2007). "La actividad formal de la Administración del Estado”. En: Derecho Administrativo Chileno, Pantoja BauzÁ, Rolando (Coord.), México D.F.: Porrúa.

Nieves Borrego, Julio (1963). "Estudio sistemático y consideración jurídico administrativa de la subvención”. Revista de Administración Pública, No 42.

Nogueira Alcalá, Humberto (2010). Derechos fundamentales y garantías constitucionales. Santiago: Librotecnia, T. IV.

Ortega Martínez, Luis et al. (1989). Corporación de Fomento de la Producción. 50 años de realizaciones: 1939-1989. Departamento de Historia, Universidad de Santiago de Chile, Santiago.

Pantoja BauZÁ, Rolando (2007). "El Derecho y la Administración del Estado en Chile”. En: Derecho Administrativo Chileno, PAnToja BAuZÁ, Rolando (Coord.), México D.F.: Editorial Porrúa.

Pantoja BauzÁ, Rolando (2008). "La tipología asumida por la Administración Pública como función estatal en su proceso adaptativo a la evolución experimentada por el Estado moderno constitucional: desde la summa potestas a la concreción humanista de la solidaridad". En: Derecho Administrativo. 120 años de Cátedra, Pantoja BAUZÁ, Rolando (Coord.), Santiago: Editorial Jurídica de Chile.

Pantoja BauzÁ, Rolando (2010). Tratado de Derecho Administrativo. Santiago: Abeledo-Perrot LegalPublishing, T. IV.

Parejo Alfonso, Luciano (2003). Derecho Administrativo. Barcelona: Ariel.

Piccinni García, Doris (1968). Teoría del decaimiento de los actos administrativos. Santiago: Editorial Jurídica de Chile.

Rivero, Jean (1984). Derecho Administrativo. Caracas, Universidad Central, Edición original de 1980 .

Rivero Jean y Waline, Jean (2000). Droit Administratif. Paris: Dalloz, 18 a Edición.

Rivero Ortega, Ricardo (2000). El Estado vigilante. Madrid: Tecnos.

Sánchez Morón, Miguel (2006). Derecho Administrativo. Parte General. Madrid: Tecnos, 2a Edición.

Santamaría Pastor, Juan Alfonso (2006). Sobre la génesis del Derecho Administrativo español en el siglo XIX (1812-1845). Madrid: Iustel, T. II.

Sayagués Lazo, Enrique (2002). Tratado de Derecho Administrativo. Montevideo: FCU, 8a Edición, T. I.

Schmidt-Assmann, Eberhard (2003). La Teoría General del Derecho Administrativo como sistema. Madrid: Marcial Pons.

Silva Cimma, Enrique (1969). Derecho Administrativo Chileno y Comparado. Santiago: Editorial Jurídica de Chile, 2a Edición.

Silva Cimma, Enrique (1995). Derecho Administrativo chileno y comparado. Actos, contratos y bienes. Santiago: Editorial Jurídica de Chile, $4^{a}$ Edición. 
Soria, Daniel Fernando (2002). "La caducidad del acto administrativo". En: Acto administrativo y procedimiento, Facultad de Derecho Universidad Austral, Buenos Aires: Ediciones RAP.

Soto Kloss, Eduardo (2009). Derecho Administrativo. Temas Fundamentales: Santiago: LegalPublishing.

Soto Velasco, Sebastián (2009). "Subsidios, permisos y condiciones: la doctrina de las condiciones inconstitucionales en Estados Unidos y su aplicación en Chile". Revista Chilena de Derecho, Vol. 36.

Stober, Rolf (1992). Derecho Administrativo Económico. Madrid: Marcial Pons, Edición original 1989.

Sunkel, Osvaldo y CARIOLA, Carmen (1982). La historia económica de Chile 18301930. Dos ensayos y una bibliografía. Madrid: Ediciones Cultura Hispánica del Instituto de Cooperación Iberoamericana.

Varas Contreras, Guillermo (1948). Derecho Administrativo. Santiago: Editorial Nascimento, 2a Edición.

Villalobos R., Sergio y Sagredo B., Rafael (1987). El proteccionismo económico en Chile. Siglo XIX. Santiago: Instituto Blas Cañas.

Villar Ezcurra, José Luis (1999). Derecho Administrativo Especial. Madrid: Civitas.

Villar Palasí, José Luis (1950). "La actividad industrial del Estado en el Derecho Administrativo". RAP, No 3.

\section{NORMAS CITADAS}

D.F.L. No 2 de 1998, Ministerio de Educación, Subvención del Estado a Establecimientos Educacionales, Diario Oficial, 28 de noviembre de 1998.

D.F.L. No 33 de 1981, Ministerio de Educación, Crea Fondo de Desarrollo Científico y Tecnológico, Diario Oficial, 27 de octubre de 1981.

D.F.L. No 4 de 1981, Ministerio de Educación, Fija normas sobre Financiamiento de las Universidades, Diario Oficial, 20 de enero de 1981.

Ley No 18.838, Crea el Consejo Nacional de Televisión, Diario Oficial, 30 de septiembre de 1989.

Ley No 18.989, Crea el Ministerio de Planificación y Cooperación, Diario Oficial, 19 de julio de 1990.

Ley No 19.227, Crea Fondo Nacional de Fomento del Libro y la Lectura, Diario Oficial, 10 de julio de 1993.

Ley No 19.302, Introduce modificaciones que indica en la Ley No 18.168, Ley General de Telecomunicaciones, Diario Oficial, 10 de marzo de 1994.

Ley No 19.496, Establece normas sobre Protección de los Derechos de los Consumidores, Diario Oficial, 7 de marzo de 1997.

Ley No 19.518, Fija nuevo Estatuto de Capacitación y Empleo, Diario Oficial, 14 de octubre de 1997. 
Ley No 19.532, Crea el Régimen de Jornada Escolar Completa Diurna, Diario Oficial, 17 de noviembre de 1997.

Ley No 19.712, Ley del Deporte, Diario Oficial, 9 de febrero de 2001.

Ley No 19.891, Crea el Consejo Nacional de la Cultura y las Artes, Diario Oficial, 23 de agosto de 2003.

Ley No 19.928, sobre Fomento de la Música Chilena, Diario Oficial, 31 de enero de 2004.

Ley No 20.000, sustituye la Ley No 19.366, que sanciona el tráfico ilícito de estupefacientes y sustancias sicotrópicas, Diario Oficial, 16 de febrero de 2005.

Ley No 20.248, Establece Ley de Subvención Escolar Preferencial, Diario Oficial, 1 de febrero de 2008.

Ley No 20.283, Ley sobre Recuperación del Bosque Nativo y Fomento Forestal, Diario Oficial, 30 de julio de 2008.

Ley No 20.378, Crea un Subsidio Nacional para el Transporte Público Remunerado de Pasajeros, Diario Oficial, 11 de mayo de 2010.

Ley No 20.433, Crea los Servicios de Radiodifusión Comunitaria Ciudadana, Diario Oficial, 4 de mayo de 2010. 